Sains Malaysiana 49(3)(2020): 593-602

http://dx.doi.org/10.17576/jsm-2020-4903-14

\title{
Cytotoxicity of L- and D-Ascorbic Acid on Murine and Human Suspension Peripheral Blood Cells
}

(Sitotoksisiti L- dan D-Asid Askorbik ke atas Sel Ampaian Darah Periferi Mencit dan Manusia)

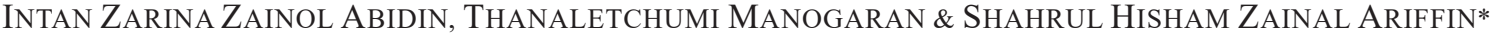

\begin{abstract}
Ascorbic acid has two isoforms, i.e., L-ascorbic acid which exists naturally and D-ascorbic acid which only can be found in synthetic form. This study aimed to determine the cytotoxic effect of $L$-and D-ascorbic acid on primary cell, i.e. murine and human suspension cells of peripheral blood. Murine and human suspension blood cells were obtained through density gradient centrifugation using Ficoll-Paque TM PLUS. Non-adherent cells were identified after 7 days in culture and seeded at $1 \times 10^{5}$ cells $/ \mathrm{mL}$. Both newly isolated primary cells were analyzed for in vitro proliferation ability for 7 days. The cells were treated with L-and D-ascorbic acid at concentrations 30, 50, and $90 \mu \mathrm{g} / \mathrm{mL}$ followed by Trypan blue viability assay at day 0, 3, 7, and 14. Cells cultured in the complete medium were represented as control. Murine and human suspension blood cells showed round morphology and significant increase of viable cells after 7 days in complete medium. Both cells treated with L-ascorbic acid exhibited low cytotoxic effect at 30, 50, and $90 \mu \mathrm{g} / \mathrm{mL}$ concentrations. In addition, murine blood cells treated with D-ascorbic acid caused total population cell death in all three concentrations at day 14, whereas human suspension blood cells only exhibited total population cell death at higher concentration, i.e. $90 \mu \mathrm{g} / \mathrm{mL}$. In conclusion, L-ascorbic acid exhibited minimal cytotoxic effect on both primary cell sources as compared to lethal effect of D-ascorbic acid treatment.
\end{abstract}

Keywords: Cytotoxicity; D-ascorbic acid; human suspension blood cells; L-ascorbic acid; Mus musculus

ABSTRAK

Asid askorbik terdiri daripada dua isoform iaitu L-asid askorbik yang wujud secara semula jadi dan D-asid askorbik yang hanya terdapat dalam bentuk sintetik. Kajian ini adalah bertujuan untuk menentukan kesan sitotoksik L-dan D-asid askorbik ke atas sel primari iaitu sel ampaian darah periferi mencit dan manusia. Sel ampaian darah mencit dan manusia diperoleh melalui kaedah pengemparan kecerunan ketumpatan menggunakan Ficoll-Paque ${ }^{\mathrm{TM}}$ PLUS. Sel ampaian dikenal pasti selepas 7 hari pengkulturan dan dikulturkan pada ketumpatan $1 \times 10^{5}$ sel/mL. Kedua-dua sumber sel yang baru dikulturkan dianalisis bagi menentukan keupayaan proliferasi in vitro selama 7 hari. Sel seterusnya dirawat dalam L-dan D-asid askorbik pada kepekatan 30, 50 dan $90 \mu \mathrm{g} / \mathrm{mL}$ diikuti dengan pengasaian keviabelan tripan biru pada hari 0, 3, 7 dan 14. Sel yang dikulturkan dalam medium lengkap mewakili kawalan. Sel ampaian darah mencit dan manusia menunjukkan morfologi bulat dan sel viabel didapati meningkat secara signifikan selepas 7 hari di dalam medium lengkap. Kedua-dua sel yang dirawat dengan L-asid askorbik menunjukkan kesan sitotoksik yang rendah pada kepekatan 30, 50 dan $90 \mu \mathrm{g} / \mathrm{mL}$. Walau bagaimanapun, sel yang dirawat dengan D-asid askorbik menyebabkan kematian sel pada ketiga-tiga kepekatan pada hari ke-14, manakala sel ampaian manusia hanya menunjukkan kematian keseluruhan sel pada kepekatan tinggi iaitu $90 \mu \mathrm{g} / \mathrm{mL}$. Kesimpulannya, L-asid askorbik menunjukkan kesan sitotoksik yang minima ke atas kedua-dua sumber sel primari berbanding kesan kematian dalam rawatan D-asid askorbik.

Kata kunci: D-asid askorbik; L-asid askorbik; Mus musculus; sel ampaian darah manusia; sitotoksisiti

\section{INTRODUCTION}

Ascorbic acid is a crucial element for metabolic function in living organisms. It is commonly known as Vitamin C or L-ascorbic acid and exists in nature. Meanwhile, another enantiomer known as D-ascorbic acid does not exist in nature and has to be synthesized (Naidu 2003; Pham-Huy et al. 2008). Many studies that have been conducted solely focused on the effects of L-ascorbic acid instead of D-ascorbic acid towards mammalian cells (Choi et al. 2008; Esteban et al. 2010; Kawada et al. 2013). Comparison between chemical structure of D-ascorbic acid and L-ascorbic acid showed a minor difference in the position of hydrogen atom that could cause a difference in cytotoxicity potential (Figure 1). Currently there is no study involved in determining the toxic effect of L-ascorbic acid versus D-ascorbic acid isoforms in primary mammalian suspension cells.

L-ascorbic acid is an antiscorbutic agent that assists wound and fracture healing via synthesis of collagen for skin and bone (Canty \& Kadler 2005; Qiao et al. 2009). 


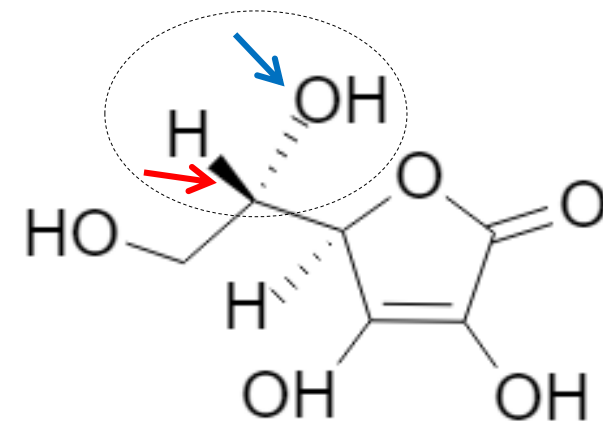

L-ascorbic acid

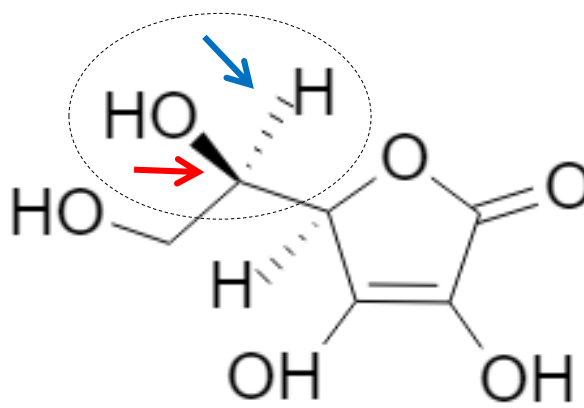

D-ascorbic acid

FIGURE 1. Chemical structure of L- and D-ascorbic acid. Wedged line (red arrow) indicates the position of the bond and the atom to the front. Dashed line (blue arrow) indicates the position of the bond and the atom to the back. Structures were drawn using ChemDraw JS online software (https://chemdrawdirect.perkinelmer.cloud/js/sample/index.html\#)

Antiscorbutic potential refers to the ability of an agent in preventing or curing scurvy disease. L-ascorbic acid also displays antioxidant properties which scavenge the free radicals, thus decelerate cell aging, protect the cell components from oxidative damage and kill the tumour cells. Unfortunately, it cannot be synthesized by human body due to the lack of L-gulono- $\gamma$-lactone oxidase enzyme as compared to mice which is able to produce endogenous vitamin $\mathrm{C}$. Therefore, human are solely dependent on an exogenous source of Vitamin $\mathrm{C}$ through their diet intake (Du et al. 2012; Pham-Huy et al. 2008; Yokoo et al. 2004). On the other hand, D-ascorbic acid displays only 2.5-5\% of antiscorbutic potential with no known significant biological role (Leung et al. 1993). However, the synthesized D-ascorbic acid was commonly used as food antioxidant in food industries especially to prevent the oxidation of meat and protect the colour in food.

Peripheral blood has been an excellent source of adult stem cells with advantages such as easily accessible and no ethical conflict. Previous studies have demonstrated that the stem cells from peripheral blood can be divided into two types; adherent and suspension blood stem cells. The adherent cells were characterized as mesenchymal stem cells, while the suspension cells were characterized as HSCs. This characterization was performed on both murine and human source of peripheral blood stem cells. The suspension blood stem cells were obtained using a combination of gradient centrifugation and culture selection (Ab Kadir et al. 2012; Ariffin et al. 2010; Hadzir et al. 2014; Yazid et al. 2011; Yuan et al. 2019). However, in this study, both isolated cell types were categorized as a population of primary mammalian suspension cells.

Various studies have demonstrated that supplementation of ascorbic acid with an appropriate dose in culture medium produced significant effect on stem cell generation, proliferation and differentiation (Ayu Suraya et al. 2018; Zhang et al. 2016). Stem cell transplantation was conducted with the aid of scaffold. The scaffolds were built using various biomaterials and act as a mechanical cue for in vitro culture and differentiation (Busra et al. 2018; Hanis et al. 2018; Shamsul et al. 2018, 2013; Shanmuganantha et al. 2018). L-ascorbic acid alone without the addition of other differentiation factors was found able to differentiate human suspension blood stem cells into osteoblasts (Hadzir et al. 2014). Other studies also looked into the potential of L-ascorbic acid derivatives as osteoblasts differentiation inducer on human bone marrow mesenchymal stem cells (BMMSC) and periodontal ligament (PDL) cells (Choi et al. 2008; Ishikawa et al. 2004). L-ascorbic acid was also found able to induce proliferation of mesenchymal stem cells derived from adipose tissue (AT-MSC) (Potdar \& D'Souza 2010). However, the level of cellular toxicity for both L- and D-ascorbic acid in primary primitive cells such as HSCs is still unknown. Hence, this study was conducted to elucidate the toxic effect of both L-and D-ascorbic acid isoforms on primary murine and human suspension blood cells.

\section{MATERIALS AND METHODS}

\section{ETHICAL APPROVAL AND SAMPLE COLLECTION}

Prior to blood sample collection, the ethical guidelines have been approved by the Research Ethics Committee (Approval number: UKM 1.5.3.5/244/02-01-02-SF1052) and Animal Ethics Committee (Approval number: FST/2015/SHAHRUL/25-MAR./664-MAR.-2015-FEB.2018-AR-CAT2) of Universiti Kebangsaan Malaysia. The blood sample from healthy human volunteers (18-25 years old) was obtained via venipuncture with informed consent. On the other hand, the blood sample from ICR strain mice (Mus musculus) (4-6 weeks old) was obtained through cardiac puncture.

\section{MURINE AND HUMAN PERIPHERAL BLOOD PRIMARY SUSPENSION CELLS ISOLATION}

The blood sample from both murine and human were drawn into the ethylenediamine tetraacetic acid (EDTA) tubes (BD, Franklin Lakes, NJ, USA) and diluted with 
phosphate buffer saline (PBS) (pH 7.4; Gibco, Grand Island, NY, USA). The diluted blood was layered on top of the Ficoll-Paque ${ }^{\mathrm{TM}}$ PLUS (GE Healthcare, Pittsburgh, PA, USA) and centrifuged at $400 \mathrm{~g}$ for $30 \mathrm{~min}$ at room temperature. After centrifugation, cells at the buffy coat layer were collected and washed with PBS thrice. The blood cells were cultured in proliferation medium containing $\alpha$-minimal essential medium (Gibco, Grand Island, NY, USA) supplemented with $10 \%(\mathrm{v} / \mathrm{v})$ newborn calf serum (Gibco, Grand Island, NY, USA) and 2\% (v/v) penicillin-streptomycin (Sigma, USA). After 7 days of culture in incubator containing $5 \%$ of $\mathrm{CO}_{2}$ at $37{ }^{\circ} \mathrm{C}$, the non-adherent blood cells which can be distinguished as cells with round morphology were suspended in the complete medium. The suspension blood cells cultured in complete medium until day 7 were used for further cellular analysis.

\section{CELL PROLIFERATION ANALYSIS}

The suspension blood cells were distinguished and isolated from the culture after 7 days and used for proliferation analysis. The cells were seeded at $1 \times 10^{5}$ cells $/ \mathrm{mL}$ in proliferation medium and counted using trypan blue exclusion assay every day for 7 days. The cells were incubated at $37{ }^{\circ} \mathrm{C}$ with $5 \% \mathrm{CO}_{2}$ and the medium was changed for every 3 days. The day of seeding is considered as day 0 .

\section{CELL SEEDING AND ASCORBIC ACID TREATMENT}

The suspension blood cells were seeded at $1 \times 10^{5}$ cells/ $\mathrm{mL}$ for cytotoxicity study using the 24 well plates. The cells cultured in proliferation medium were added with either L- or D-ascorbic acid (Sigma Aldrich, USA) at concentrations of 30,50 , and $90 \mu \mathrm{g} / \mathrm{mL}$, respectively. The cells in proliferation medium (normal medium without ascorbic acid) acted as control (complete medium). The suspension blood cells were incubated at $37{ }^{\circ} \mathrm{C}$ with $5 \%$ $\mathrm{CO}_{2}$ and the medium was changed every 3 days. Viability analysis was performed at day $0,3,7$, and 14 in the presence of various concentrations of ascorbic acid (The day of ascorbic acid treatment started was considered as day 0 ). Murine and human suspension blood cells were tested separately.

\section{TRYPAN BLUE EXCLUSION ASSAY}

Viability analysis was determined using trypan blue exclusion assay and conducted at day $0,3,7$, and 14. A total of $10 \mu \mathrm{L}$ of suspension peripheral blood cells were mixed with $10 \mu \mathrm{L}$ of $0.4 \%$ trypan blue solution (Life Technologies, Grand Island, NY, USA). The cells stained in blue colour were dead cells and the cells with halo-like and colourless appearance were viable cells. The number of viable cells was determined using haemocytometer and mean \pm standard deviation was given for three biological replicates $(n=3)$ where each biological replicate consists of three readings.

\section{STATISTICAL ANALYSIS}

Statistical analysis was performed using Student's t-test where $p<0.05$ was considered as statistically significant.

\section{RESULTS AND DisCUSSION}

\section{ISOLATION AND MORPHOLOGY OF PRIMARY SUSPENSION BLOOD CELLS}

The cell morphology of murine and human primary suspension blood cells was observed under an inverted microscope. As shown in Figure 2(A) and 2(B), the suspension blood cells of both murine and human origins indicated a round morphology with halo-like appearance. In this study, the murine and human suspension blood cells were cultured in the presence of complete medium for 7 days before both cells were tested separately with L- and $\mathrm{D}$-ascorbic acid isoforms. This allows a successful isolation of murine and human suspension blood cells after density gradient centrifugation and a seven-day culture selection approach. During this time frame, culture selection takes place where fully differentiated and mature cell population and other precursor cells would die due to limited shelf life (Ariffin et al. 2010; Hadzir et al. 2014; Yazid et al. 2011; Yuan et al. 2019).

\section{IN VITRO POPULATION OF MURINE AND HUMAN SUSPENSION BLOOD CELLS}

Trypan blue is one of the common dye exclusion assay used to determine the number of viable cells present in cell suspension (Strober 2001). As a membrane selective dye, trypan blue dye can penetrate the cell membrane and indicate the dead or non-viable cells in blue colour whereas viable cells appear colourless due to intact and nonpermeable cell membrane (Strober 2001; Tran et al. 2011). Previous studies have shown that the viability of suspension cell can be analysed using trypan blue exclusion method (Ariffin et al. 2010; Hadzir et al. 2014; Shahrul Hisham et al. 2016; Strober 2001). The use of trypan blue is not only limited to suspension cells but can also be used to assess the viability of adherent cells (Ravinanthanan et al. 2018; Wan Haifa Haryani et al. 2010). Trypan blue exclusion method can determine the cell survival ability post isolation, i.e. from in vivo to in vitro microenvironment and cell proliferation during in vitro culture (Intan Zarina et al. 2010). Peripheral blood cells used in this study are in suspension form, therefore trypan blue exclusion assay was chosen instead of MTT assay.

Proliferation analysis of murine suspension blood cells showed a significant increase $(p<0.05)$ in the number of viable cells from day 1 onwards as compared to day 0 (Figure 3(A)). Meanwhile, Figure 3(B) exhibited proliferation analysis of human suspension blood cells which also indicated a significant increase $(p<0.05)$ in the number of viable cells starting from day 2 until 7 as compared to day 0 . Proliferation analyses showed that both cells are highly viable and capable of self-renewal. Since 

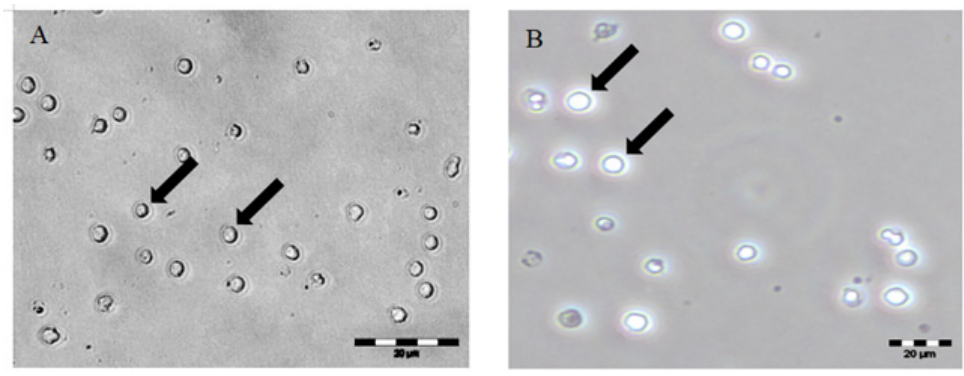

FIGURE 2. Morphology of (A) murine and (B) human suspension blood stem cells after 7 days of isolation before cytotoxicity test. Viable cells exhibited round and halo-like appearance (arrow). Magnification: 100X

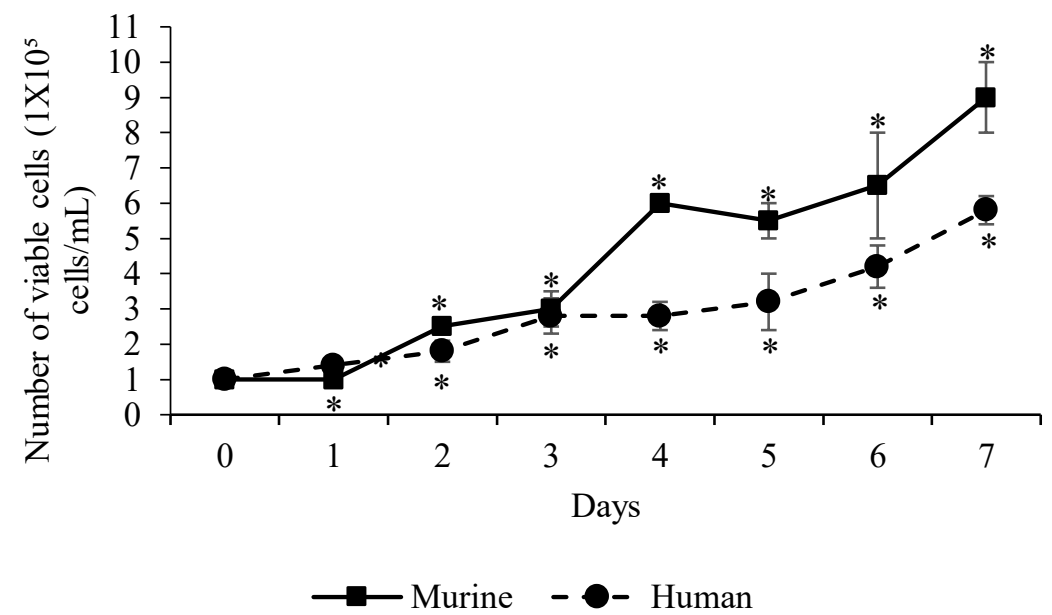

FIGURE 3. Proliferation of isolated murine and human suspension blood stem cells cultured in complete medium for 7 days. Mean \pm standard error of mean was given from three biological replicates $(n=3)$. *statistical significance $(\mathrm{p}<0.05)$ as compared to day 0

both cells possess in vitro proliferative ability, any cytotoxic effect from ascorbic acid isoforms would drastically inhibit the cell growth or may cause cell death. A significant increase $(p<0.05)$ in the viable cells for both cell types indicated that the suspension blood cells have self-replicative ability. High expansion potential of HSCs has been published by multiple researchers (Ab Kadir et al. 2012, 2011; Ariffin et al. 2010; Intan Zarina et al. 2010). Proliferation ability is not only important during cell growth but is also tightly regulated during differentiation mechanism (Lange \& Calegari 2010).

\section{CYTOTOXIC EFFECTS OF L-ASCORBIC ACID AND D-ASCORBIC ACID ISOFORMS}

In this study, we would like to determine the effect of two different ascorbic acid isoforms on murine and human suspension blood cells. Two isoforms of ascorbic acid which are L-ascorbic acid and D-ascorbic acid were used. L-ascorbic acid is widely used for cell culture studies due to its beneficial properties and was also extensively used in osteoblasts differentiation upon many sources of cells (Gorrini et al. 2013; Graneli et al. 2014; Kermani et al. 2014; Kim et al. 2012; Kyllonen et al. 2013; Maroon et al. 2010; Montecinos et al. 2007; Rohaya et al. 2017; Shahrul Hisham et al. 2017). Its role in the bone formation in human body was well-established where proline and lysine hydroxylation is dependent on ascorbic acid as cofactor which eventually forms collagen Type I. This particular type of collagen is abundant in bone, approximately more than 95\% (Murad et al. 1981; Yamauchi \& Sricholpech 2012).

As for D-ascorbic acid, no prior studies were conducted on cell lines or primary cell cultures. Most of the in vitro osteoblast differentiation studies used L-ascorbic acid at the concentration of $50 \mu \mathrm{g} / \mathrm{mL}$ along with other differentiation factors (Farinawati et al. 2019, 2018; Kawaguchi et al. 1999; Nam et al. 2011; Tran Hle et al. 2015). In this study, we also observed the effect of ascorbic acid using three concentrations, i.e. 30, 50, and $90 \mu \mathrm{g} / \mathrm{mL}$. It was found that proliferation or differentiation of MSC were dependent on ascorbic acid concentration (Choi et al. 2008). Therefore, the concentrations of 30, and $90 \mu \mathrm{g} / \mathrm{mL}$ were chosen to represent a lower and higher concentration than $50 \mu \mathrm{g} / \mathrm{mL}$.

Cytotoxic effect of L-and D-ascorbic acid isoforms toward murine suspension blood cells

The effect of L-ascorbic acid at 30, 50, and $90 \mu \mathrm{g} / \mathrm{mL}$ concentrations on murine suspension cells for 14 days is shown in Figure 4(A). Day 0 for all treatments were 
represented as $10^{5}$ viable cells. Control cells that was cultured in complete medium proliferated normally, thus exhibited a significant increase $(p>0.05)$ in the number of viable cells when compared to day 0 . However, L-ascorbic acid treatment on the murine suspension blood cells treated until day 14 showed no significant changes $(p>0.05)$ in viable cell number as compared to the cells at day 0 . Although the concentrations of L-ascorbic acid and incubation days were increased, the number of viable cells still remained similar throughout treatment (Figure 4(A)). This is an indication that L-ascorbic acid concentrations produced cellular survival signals by maintaining the number of viable cells throughout 14 days of exposure.
Figure 4(B) represents the murine suspension blood cells treated with 30,50 , and $90 \mu \mathrm{g} / \mathrm{mL}$ D-ascorbic acid for 14 days. At day 0, all treatments were represented as $10^{5}$ viable cells. Contrast with L-ascorbic acid, D-ascorbic acid treatment indicated significant decrease $(p<0.05)$ in the number of viable cells at day 3 and 7 as compared to day 0 and total cell death at day 14. This also indicated that when incubation days were increased, the number of viable cells in all tested D-ascorbic acid concentrations were decreased $(p<0.05)$ as compared to the cells cultured from previous day. In contrast, for control (complete medium), the cells indicated a significant increase $(p<0.05)$ in the number of viable cells when cultured at day 3,7 ,

A

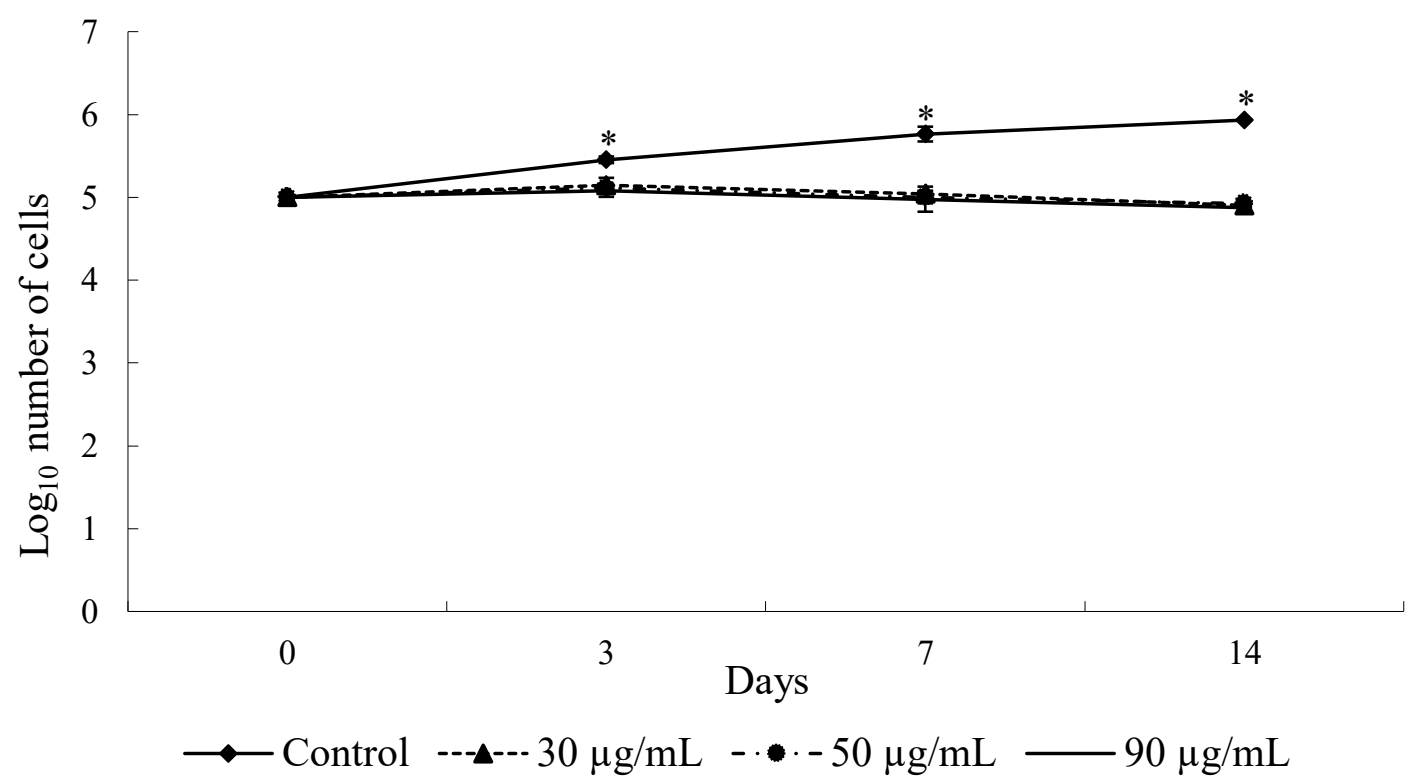

$\mathrm{B}$

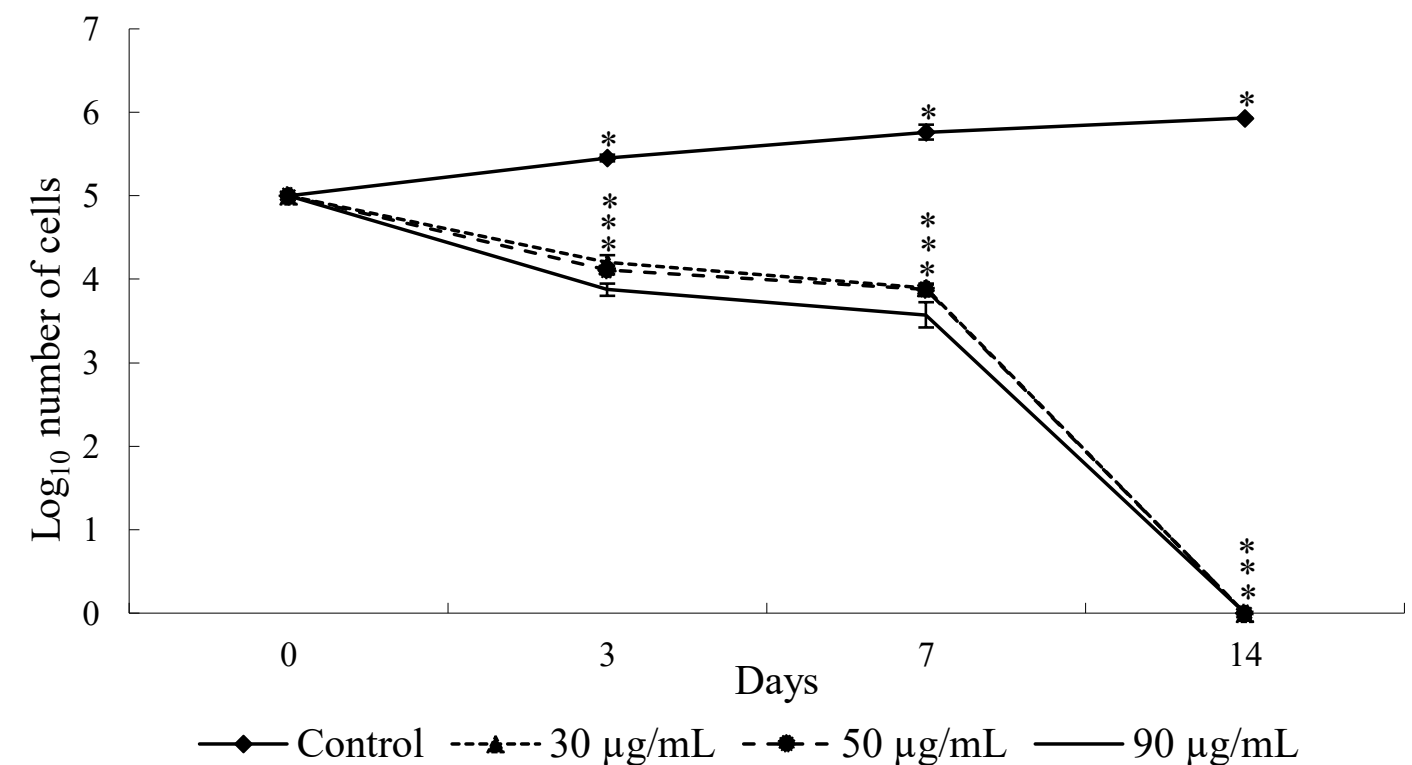

FIGURE 4. Effect of (A) L- and (B) D-ascorbic acid on proliferation of murine suspension blood cells. Mean \pm standard error of mean was given from three biological replicates $(n=3)$. L-ascorbic acid had no significant cytotoxic effect on murine suspension blood stem cells. D-ascorbic acid showed lethal effect on cells at day $14 ;{ }^{*} \mathrm{p}<0.05$ 
and 14 as compared to day 0 (Figure 4(B)). Although not many studies on cytotoxicity of L-ascorbic acid upon murine cells or cells were performed, this isoform was introduced on mice induced pluripotent stem cells (iPSC) at the concentration of 25 or $50 \mu \mathrm{g} / \mathrm{mL}$. L-ascorbic acid was found able to enhance iPSC generation and can convert pre-iPSC to iPSC so that the cells can achieve a pluripotent state. The addition of L-ascorbic acid also elongated the lifespan of iPSC by increasing its proliferation potential thus, bypassed the cell senescence (Esteban et al. 2010). However, murine cell sources indicated a decrease in cell viability as the concentration of L-ascorbic acid increased. This showed that an optimum concentration of L-ascorbic acid is needed to induce proliferation of murine cells without killing them. The murine osteoblasts precursor, i.e., MC3T3-E1 cell line was previously tested with L-ascorbic acid. It showed a significant increase in the ALP production and the formation of osteoblasts which was determined via von Kossa staining protocol (Intan Zarina et al. 2018; Shiga et al. 2003). From these studies, we can postulate that $\mathrm{L}$-ascorbic acid could induce differentiation of MC3T3-E1 cells using proper concentration. In our study, the number of murine suspension blood cells treated with $30-90 \mu \mathrm{g} / \mathrm{mL}$ of $\mathrm{D}$-ascorbic acid were found to be decreased significantly until total population cell death was observed at day 14 (Figure 4(B)). This indicated that $\mathrm{D}$-ascorbic acid isoform can cause lethal toxicity effect on murine suspension blood cells after 14 days of treatment.

Human suspension blood cells cytotoxic effect of $L$ - and $D$ - ascorbic acid isoforms

Human suspension blood cells were also cultured in different ascorbic acid isoforms (L- and D-) at three different concentrations, i.e., 30, 50, and $90 \mu \mathrm{g} / \mathrm{mL}$. Figure 5 (A) shows the effect of 30,50 , and $90 \mu \mathrm{g} / \mathrm{mL}$ of L-ascorbic acid on human suspension blood cells cultured for 14 days. The cell number at day 0 for all treatments was represented as $10^{5}$ viable cells. Based on Figure 5(A), control cells cultured in complete medium showed a significant increase $(p<0.05)$ in viable cell numbers throughout 14 days of culture with the highest viable cells at approximately 2.5 $\times 10^{6}$ cells. During L-ascorbic acid treatment, the number of viable cells for all concentrations showed a significant decrease $(p<0.05)$ as compared to day 0 (Figure 5(A)). Although a significant reduction of cell viability at all concentrations was observed, the human suspension blood cells still exhibited the presence of viable cells at all three concentrations until 14 days of exposure (Figure 5(A)).

Meanwhile, the viability profile of the human suspension blood cells exposed with 30,50 , and $90 \mu \mathrm{g} / \mathrm{mL}$ D-ascorbic acid for 14 days was also displayed in Figure 5(B). D-ascorbic acid treatment showed a significant decrease $(p<0.05)$ in the number of viable cells as compared to day 0 (Figure 5(B); 30, 50, and $90 \mu \mathrm{g} / \mathrm{mL}$ ). The number of viable cells had decreased gradually when the incubation days were increased in all three concentrations. In addition, no viable cells were observed in the presence of $90 \mu \mathrm{g} / \mathrm{mL}$ of D-ascorbic acid for 14 days, i.e. cells experienced complete cell death in this concentration.

Previously, a study on the breast cancer and normal cell lines treated with $0.1-1.0 \mathrm{mM}$ of L-ascorbic acid found that the normal cell lines survived while the cancer cell lines underwent cell death. Similarly, the human leukemic cell lines which were treated with $0.28-2.80 \mathrm{mM}$ of L-ascorbic acid for an hour had indicated apoptosis, while the normal hematopoietic stem cells or progenitor cells survived. These studies showed that L-ascorbic acid has anticancer properties that selectively kills the cancer cells at a low concentration in contrast with the normal cells and stem cells that exhibited the presence of viable cells (Kawada et al. 2013).

In addition, a study on the BMMSC reported that L-ascorbate-2-phosphate enhanced cell proliferation (initial seeding density of $10^{4}$ cells/well) tremendously with increased ascorbic acid concentrations (5-250 mM). However, the addition of $0.5 \mathrm{mM}$ of ascorbic acid reduced the cell viability which occurred probably due to the induction of cell death (Choi et al. 2008). Comparative to this study, human and murine suspension blood stem cells produce approximately similar or lower number of viable cells, respectively at $0.17-0.51 \mathrm{mM}$ of L-ascorbic acid (equivalent to $30-90 \mu \mathrm{g} / \mathrm{mL}$ ).

Comparison between murine and human suspension cells exposed with $L$ - and D-ascorbic acid isoforms

In the human suspension blood cells, the cells survived better in L-ascorbic acid as compared to D-ascorbic acid treatment during the culture period. On the other hand, the murine suspension blood cells also survived well for 14 days in L-ascorbic acid treatment. However, both cells exhibited a decrease in the number of viable cells when exposed to D-ascorbic acid. It is implicated that D-ascorbic acid is unsuitable for both murine and human suspension blood cells. In contrast, L-ascorbic acid at all concentrations (30, 50, and $90 \mu \mathrm{g} / \mathrm{mL})$ did not cause much detrimental effect on both murine and human suspension cells.

The effect of 30,50 , and $90 \mu \mathrm{g} / \mathrm{mL}$ for both isoforms on murine and human suspension blood cells at day 7 and 14 were compared (Figure 6). For L-ascorbic acid on the murine suspension blood primary cells, all L-ascorbic acid concentrations indicated that the cell survival were maintained at approximately $95 \%$ at both day 7 and 14 . Similarly, when the human suspension blood cells were incubated in L-ascorbic acid, the percentage of cell survival were slightly decreased to a certain extent approximately $90 \%$ for all three L-ascorbic acid concentrations at day 7 and 14.

While for D-ascorbic acid at day 7, both murine and human blood cells showed a significant reduction in the percentage of viable cells $(p<0.05)$ when treated with D-ascorbic acid as compared to L-ascorbic acid which were below $80 \%$. Furthermore, treatment of murine suspension cells at day 14 with D-ascorbic acid displayed 

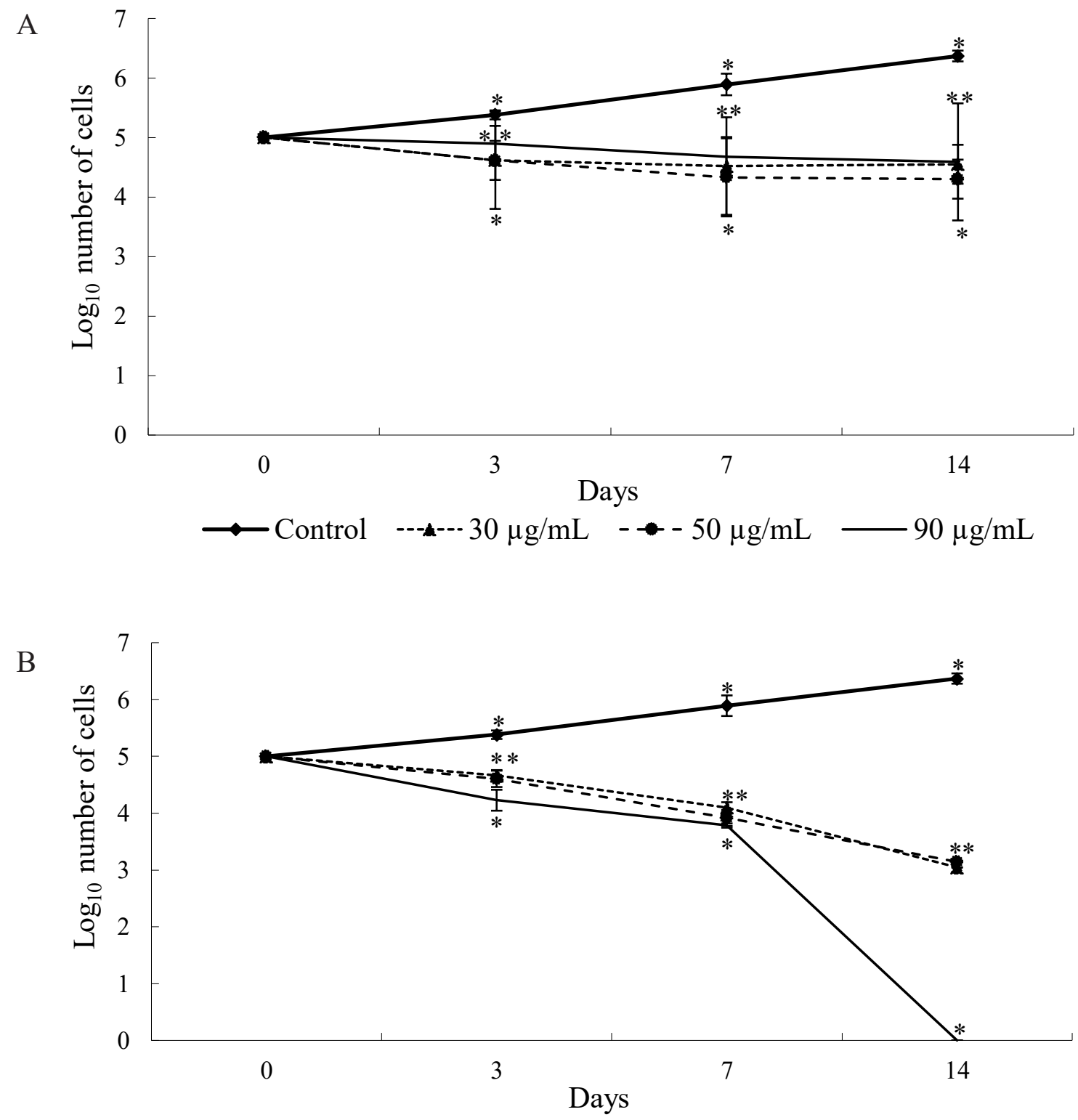

$\longrightarrow$ Control $\rightarrow---30 \mu \mathrm{g} / \mathrm{mL} \rightarrow-50 \mu \mathrm{g} / \mathrm{mL} \longrightarrow 90 \mu \mathrm{g} / \mathrm{mL}$

FIGURE 5. Effect of (A) L- and (B) D-ascorbic acid on proliferation of human suspension blood cells. Mean \pm standard error of mean was given from three biological replicates $(n=3)$. D-ascorbic acid showed higher cytotoxic effect on cells as compared to

L-ascorbic acid. No viable cells were detected after treatment in $90 \mu \mathrm{g} / \mathrm{mL}$ D-ascorbic acid at day 14; * $<<0.05$

no viable cells at all three concentrations, hence it exhibited a lethal effect to the murine suspension cells. On the other hand, the human suspension blood cells demonstrated lethal effect only in $90 \mu \mathrm{g} / \mathrm{mL}$ of D-ascorbic acid treatment at day 14 (Figure 5), i.e. a total population of cell death in this condition. However, 30 and $50 \mu \mathrm{g} / \mathrm{mL}$ of D-ascorbic acid treatments only showed toxic effects towards human suspension blood cells. This is proven by a significant decrease $(p<0.05)$ in the percentage of viable cells $(<65 \%)$ which can be observed for both 30 and $50 \mu \mathrm{g} / \mathrm{mL}$ of D-ascorbic acid treatment at day 14 (Figure 6). This is an indication that $\mathrm{D}$-ascorbic acid exhibited higher cytotoxic effect towards murine cells as compared to the human cells. Therefore, L- ascorbic acid maintained the survival for both murine and human suspension blood cells. In contrast, D-ascorbic acid showed lethal effect to the murine suspension blood cells and exhibited toxic effects upon human suspension blood cells with lethal effect only shown at $90 \mu \mathrm{g} / \mathrm{mL}$ after exposure for 14 days.

During in vitro cell culture, L-ascorbic acid has shown better proliferation potential at concentration below $50 \mu \mathrm{g} /$ $\mathrm{mL}$ with similar potential in the normal cell lines (Esteban et al. 2010). However, treatment of L-ascorbic acid in cancer cells showed cell death when concentration as low as $15 \mu \mathrm{g} / \mathrm{mL}$ was utilized (Kawada et al. 2013). This indicates that L-ascorbic acid can selectively kill cancerous cells without harming the normal cells. Meanwhile, D-ascorbic acid may lack such selectiveness since it kills 


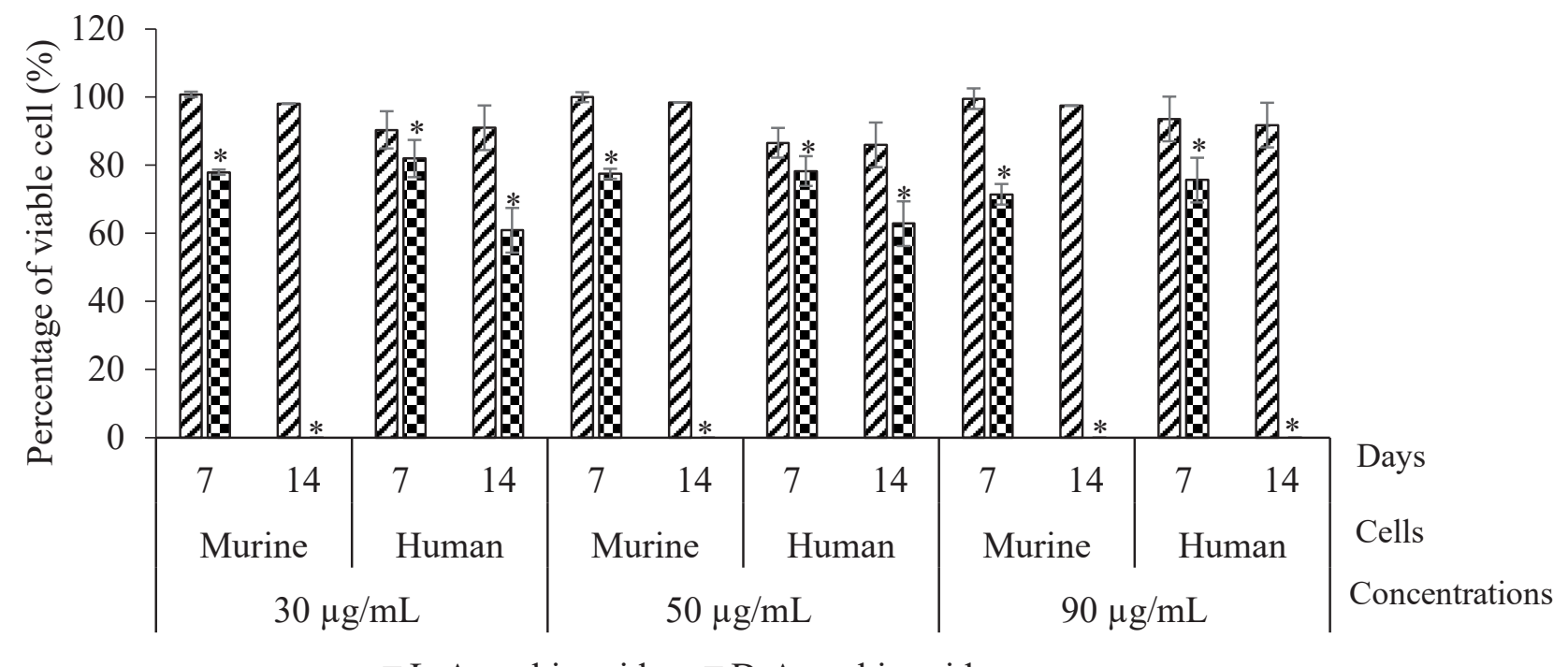

$\square$ L-Ascorbic acid $\quad$ D-Ascorbic acid

FIGURE 6. Comparison of L- and D-ascorbic acid toxicity effects on murine and human suspension blood cells after 7 and 14 days treatment. Mean \pm standard error of mean was given from three biological replicates $(n=3) ;{ }^{*} p<0.05$

both normal and cancer cells at concentration above 100 $\mu \mathrm{g} / \mathrm{mL}$ (Miura et al. 2015). This is probably the reason behind cell death observed during D-ascorbic acid treatment on both murine and human suspension blood cells at day 14.

\section{CONCLUSION}

Murine and human source of suspension blood cells display almost similar results due to their genetic similarity. Both cell types showed the ability to survive in the presence of L-ascorbic acid. In contrast, D-ascorbic acid was found to exhibit lethal effect on the murine blood cells, whereas exhibited cytotoxic effect on the human blood cells with lethal effect only showed at $90 \mu \mathrm{g} / \mathrm{mL}$ after 14 days of exposure. This indicated that the natural L-ascorbic acid is a better option for both in vitro and in vivo studies in mammalian compared to the synthetic D-ascorbic acid where the concentration used should not exceed $90 \mu \mathrm{g} / \mathrm{mL}$. The knowledge gained from this study can be further used to study the effect of L-ascorbic acid alone on in vitro primary cells and cell lines as well as in vivo model.

\section{ACKNOWLEDGEMENTS}

This work was funded by a grant from Ministry of Higher Education (MOHE), Malaysia (FRGS/1/2018/STG05/ CUCMS/02/1).

\section{REFERENCES}

Ab Kadir, R., Zainal Ariffin, S.H., Megat Abdul Wahab, R., Kermani, S. \& Senafi, S. 2012. Characterization of mononucleated human peripheral blood cells. The Scientific World Journal 2012: Article ID. 843843.
Ab Kadir, R., Ariffin, S.H.Z., Megat Abdul Wahab, R., Senafi, S. \& Huyop, F.Z. 2011. Differentiation potential of human suspension mononucleated peripheral blood cells. African Journal of Biotechnology 10: 10756.

Ariffin, S.H.Z., Abidin, I.Z.Z., Yazid, M.D. \& Wahab, R.M.A. 2010. Differentiation analyses of adult suspension mononucleated peripheral blood cells of Mus musculus. Cell Communication and Signaling 8: 29.

Ayu Suraya, A., Muhammad Dain, Y., Nur Qisya Afifah Veronica, S., Rabiatul Adawiyah, R., Aminuddin, S. \& Ruszymah, B.H.I. 2018. Osteogenic induction of Wharton's jelly-derived mesenchymal stem cell for bone regeneration: A systematic review. Stem Cells International 2018: Article ID. 2406462.

Busra, F.M., Lokanathan, Y., Nadzir, M.M., Saim, A., Idrus, R.B.H. \& Chowdhury, S.R. 2018. Attachment, proliferation, and morphological properties of human dermal fibroblasts on ovine tendon collagen scaffolds: A comparative study. The Malaysian Journal of Medical Sciences 24(2): 33-43.

Canty, E.G. \& Kadler, K.E. 2005. Procollagen trafficking, processing and fibrillogenesis. Journal of Cell Science 118: 1341-1353.

Choi, K.M., Seo, Y.K., Yoon, H.H., Song, K.Y., Kwon, S.Y. \& Lee, H.S. 2018. Effect of ascorbic acid on bone marrow-derived mesenchymal stem cell proliferation and differentiation. Journal of Biosciences and Bioengineering 105: 586-594.

Du, J., Cullen, J.J. \& Buettner, G.R. 2012. Ascorbic acid: Chemistry, biology and the treatment of cancer. Biochimica et Biophysica Acta Reviews for Cancer 1826: 443-457.

Esteban, M.A., Wang, T., Qin, B.M., Yang, J.Y., Qin, D.J. \& Cai, J.L. 2010. Vitamin C enhances the generation of mouse and human induced pluripotent stem cells. Cell Stem Cell 6: 71-79.

Farinawati, Y., Nur Atmaliya, L., Rohaya, M.A.W., Shahrul Hisham, Z.A. \& Sahidan, S. 2018. Proliferation and osteoblast differentiation mice dental pulp stem cells between enzyme digestion and outgrowth method. Sains Malaysiana 47(4): 691-698. 
Farinawati, Y., Amy, N.M.K., Wong, Y.Q., Nur Atmaliya, L., Shahrul Hisham, Z.A. \& Rohaya, M.A.W. 2019. Morphology and osteogenic capability of MC3T3-E1 cells on granular hydroxyapatite scaffold. Journal of Biological Sciences 19(3): 201-209.

Gorrini, C., Harris, I.S. \& Mak, T. 2013. Modulation of oxidative stress as an anticancer strategy. Nature Reviews on Drug Discovery 12: 931-947.

Granéli, C., Thorfve, A., Ruetschi, U., Brisby, H., Thomsen, P. \& Lindahl, A. 2014. Novel markers of osteogenic and adipogenic differentiation of human bone marrow stromal cells identified using a quantitative proteomics approach. Stem Cell Research 12: 153-165.

Hadzir, S.N., Ibrahim, S.N., Abdul Wahab, R.M., Zainol Abidin, I.Z., Senafi, S. \& Ariffin, Z.Z. 2014. Ascorbic acid induces osteoblast differentiation of human suspension mononuclear cells. Cytotherapy 16: 674-682.

Hanis, H., Mohd Reusmaazran, Y., Zainul Rashid, M.R., Ruszymah, I. \& Chowdhury, S.R. 2018. Human amniotic membrane with aligned electrospun fiber as scaffold for aligned tissue regeneration. Tissue Engineering Part $C$ Methods 24: 368-378.

Intan Zarina, Z.A., Puteri Haslin Nadya, H. \& Shahrul Hisham, Z.A. 2018. Cyotoxic effect of Piper sarmentosum on MC3T3-E1 cell line and differentiation potential towards osteoblast. In Research Series Biosciences and Biotechnology, edited by Zamri, Z. Universiti Kebangsaan Malaysia. p.189.

Intan Zarina, Z.A., Shahrul Hisham, Z.A., Zaidah, Z.A. \& Rohaya, M.A.W. 2010. Potential differentiation of three types of primitive cells originated from different proliferation terms of mouse blood. Sains Malaysiana 39: 305-313.

Ishikawa, S., Iwasaki, K., Komaki, M. \& Ishikawa, I. 2004. Role of ascorbic acid in periodontal ligament cell differentiation. Journal of Periodontology 75: 709-716.

Kawada, H., Kaneko, M., Sawanobori, M., Uno, T., Matsuzawa, H. \& Nakamura, Y. 2013. High concentrations of L-ascorbic acid specifically inhibit the growth of human leukemic cells via downregulation of HIF-1alpha transcription. PLOS ONE 8: e62717.

Kawaguchi, H., Manabe, N., Miyaura, C., Chikuda, H., Nakamura, K. \& Kuro-O, M. 1999. Independent impairment of osteoblast and osteoclast differentiation in klotho mouse exhibiting low-turnover osteopenia. Journal of Clinical Investigation 104: 229-237.

Kermani, S., Megat Abdul Wahab, R., Zainol Abidin, I.Z., Zainal Ariffin, Z., Senafi, S. \& Zainal Ariffin, S.H. 2014. Differentiation capacity of mouse dental pulp stem cells into osteoblasts and osteoclasts. Cell Journal 16: 31-42.

Kim, B.C., Bae, H., Kwon, I.K., Lee, E.J., Park, J.H. \& Khademhosseini, A. 2012. Osteoblastic/cementoblastic and neural differentiation of dental stem cells and their applications to tissue engineering and regenerative medicine. Tissue Engineering Part B Reviews 18(3): 235244.

Kyllönen, L., Haimi, S., Mannerström, B., Huhtala, H., Rajala, K.M. \& Skottman, H. 2013. Effects of different serum conditions on osteogenic differentiation of human adipose stem cells in vitro. Stem Cell Research and Therapy 4(1): 17

Lange, C. \& Calegari, F. 2010. Cdks and cyclins link G1 length and differentiation of embryonic, neural and hematopoietic stem cells. Cell Cycle 9: 1893-1900.
Leung, P.Y., Miyashita, K., Young, M. \& Tsao, C.S. 1993. Cytotoxic effect of ascorbate and its derivatives on cultured malignant and nonmalignant cell lines. AntiCancer Research 13: 475-480.

Maroon, J.C., Bost, J.W. \& Maroon, A. 2010. Natural antiinflammatory agents for pain relief. Surgical Neurology International 1: 80

Miura, K., Yazama, F. \& Tai, A. 2015. Oxidative stressmediated antitumor activity of erythorbic acid in high doses. Biochemistry and Biophysical Reports 3: 117-122.

Montecinos, V., Guzman, P., Barra, V., Villagran, M., MunozMontesino, C. \& Sotomayor, K. 2007. Vitamin C is an essential antioxidant that enhances survival of oxidatively stressed human vascular endothelial cells in the presence of a vast molar excess of glutathione. Journal of Biological Chemistry 282(21): 15506-15515.

Murad, S., Grove, D., Lindberg, K.A., Reynolds, G., Sivarajah, A. \& Pinnell, S.R. 1981. Regulation of collagen synthesis by ascorbic acid. Proceedings of the National Academy Sciences of United States of America 78: 2879-2882.

Nam, S., Won, J.E., Kim, C.H. \& Kim, H.W. 2011. Odontogenic differentiation of human dental pulp stem cells stimulated by the calcium phosphate porous granules. Journal of Tissue Engineering 2011: 812547.

Naidu, K.A. 2003. Vitamin C in human health and disease is still a mystery? An overview. Nutrition Journal 2: 7. doi: 10.1186/1475-2891-2-7.

Pham-Huy, L.A., He, H. \& Pham-Huy, C. 2008. Free radicals, antioxidants in disease and health. International Journal of Biomedical Science 4: 89-96.

Potdar, P.D. \& D'Souza, S.B. 2010. Ascorbic acid induces in vitro proliferation of human subcutaneous adipose tissue derived mesenchymal stem cells with upregulation of embryonic stem cell pluripotency markers Oct 4 and SOX 2. Human Cell 23(4): 152-155.

Qiao, H., Bell, J., Juliao, S., Li, L. \& May, J.M. 2009. Ascorbic acid uptake and regulation of type I collagen synthesis in cultured vascular smooth muscle cells. Journal of Vascular Research 46: 15-24.

Ravinanthanan, M., Hedge, M.N., Shetty, V. \& Kumari, S. 2018. Cytotoxicity evaluation of combinations irrigant regimens with MTAD on two different cell lines. Contemporary Clinical Dentistry 9: 255-259.

Rohaya, M.A.W., Nur Akmal, M.R., Sahidan, S., Intan Zarina, Z.A., Zaidah, Z.A. \& Shahrul Hisham, Z.A. 2017. Impact of isolation method on doubling time and the quality of chondrocyte and osteoblast differentiated from murine dental pulp stem cells. PeerJ 14(5): e3180.

Shahrul Hisham, Z.A., Thanaletchumi, M., Intan Zarina, Z.A., Rohaya, M.A.W. \& Sahidan, S. 2017. A perspective on stem cells as biological systems that produce differentiated osteoblasts and odontoblasts. Current Stem Cell Research \& Therapy 12(3): 247-259.

Shahrul Hisham, Z.A., Nur Akmal, M.R., Rohaya, M.A.W., Sahidan, S., Intan Zarina, Z.A. \& Zaidah, Z.A. 2016. Analyses of basal media and serum for in vitro expansion of suspension peripheral blood mononucleated stem cell. Cytotechnology 68(4): 675-686.

Shamsul, S., Tan, K.K., Chen, H.C., Aminuddin, S. \& Ruszymah, I. 2013. Tricalcium phosphate/hydroxyapatite (TCP-HA) bone scaffold as potential candidate for the formation of tissue engineered bone. Indian Journal of Medical Research 137: 1093-1101. 
Shamsul, B.S., Chowdhury, S.R., Ruszymah, B.H.I. \& Nor Hamdan, B.M.Y. 2018. Effects of PLGA nanofibre on osteoarthritic chondrocytes. Sains Malaysiana 47(10): 2325-2336.

Shanmuganantha, L., Azmi, B., Abdul, H.A.R., Nor Hazla, M.H., Sabaru, A.M. \& Ruszymah, B.H.I. 2018. Role of titanium-wollastonite in promoting mesenchymal stem cells growth. Regenerative Research 7: 28-30.

Shiga, M., Kapila, Y.L., Zhang, Q., Hayami, T. \& Kapila, S. 2003. Ascorbic acid induces collagenase-1 in human periodontal ligament cells but not in MC3T3-E1 osteoblast-like cells: Potential association between collagenase expression and changes in alkaline phosphatase phenotype. Journal of Bone and Mineral Research 18: 67-77.

Strober, W. 2001. Trypan blue exclusion test of cell viability. Current Protocols in Immunology. doi: 10.1002/0471142735. ima03bs 21 .

Tran Hle, B. \& Doan, V.N. 2015. Human dental pulp stem cells cultured onto dentin derived scaffold can regenerate dentin-like tissue in vivo. Cell and Tissue Banking 16: 559-568.

Tran, S., Puhar, A., Ngo-Camus, M. \& Ramarao, N. 2011. Trypan blue dye enters viable cells incubated with the poreforming toxin HlyII of Bacillus cereus. PLoS ONE 6(9): e22876.

Wan Haifa Haryani, W.O., Shahrul Hisham, Z.A., Zaidah, Z.A., Muhd Fauzi, S., Sahidan, S. \& Rohaya, M.A.W. 2010. Anticancer screening of ethanol extract from selected piperaceae family and its determination via trypan blue staining. Sains Malaysiana 39(6): 941949.

Yamauchi, M. \& Sricholpech, M. 2012. Lysine post-translational modifications of collagen. Essays of Biochemistry 52: 113133.

Yazid, M.D., Zainal Ariffin, S.H., Senafi, S., Zainal Ariffin, Z. \& Megat Abdul Wahab, R. 2011. Stem cell heterogeneity of mononucleated cells from murine peripheral blood: Molecular analysis. The Scientific World Journal 11: 340278 .
Yokoo, S., Furumoto, K., Hiyama, E. \& Miwa, N. 2004. Slowdown of age-dependent telomere shortening is executed in human skin keratinocytes by hormesis-like-effects of trace hydrogen peroxide or by anti-oxidative effects of pro-vitamin $\mathrm{C}$ in common concurrently with reduction of intracellular oxidative stress. Journal of Cell Biochemistry 93: 588-597.

Yuan, X., Cao, X. \& Yang, S.Y. 2019. IFT80 is required for stem cell proliferation, differentiation, and odontoblast polarization during tooth development. Cell Death and Disease 10(2): 63

Zhang, P., Li, J., Qi, Y., Zou, Y., Liu, L. \& Tang, X. 2016. Vitamin $\mathrm{C}$ promotes the proliferation of human adiposederived stem cells via p53-p21 pathway. Organogenesis 12: 143-151.

Intan Zarina Zainol Abidin

Centre for Research and Graduate Studies

University of Cyberjaya

63000 Cyberjaya, Selangor Darul Ehsan

Malaysia

Thanaletchumi Manogaran \& Shahrul Hisham Zainal Ariffin*

Centre for Biotechnology and Functional Food

Faculty of Science and Technology

Universiti Kebangsaan Malaysia

43600 UKM Bangi, Selangor Darul Ehsan

Malaysia

Shahrul Hisham Zainal Ariffin*

Malaysian Genome Institute (MGI)

National Institute of Biotechnology Malaysia (NIBM)

Jalan Bangi, 43600 Kajang, Selangor Darul Ehsan

Malaysia

*Corresponding author; email: hisham@ukm.edu.my

Received: 29 July 2019

Accepted: 18 November 2019 